\title{
OPTIMISM AND PSYCHOLOGICAL DISTRESS AMONG FIRST- YEAR STUDENTS DURING THE COVID-19 PANDEMIC
}

\author{
Rodiyah \\ Fakultas Psikologi, Universitas Hang Tuah \\ J1. Arif Rahman Hakim No. 150, Keputih, Sukolilo, Surabaya, Indonesia 60111 \\ Rodiyah.rodiyah@hangtuah.ac.id
}

\begin{abstract}
The Covid-19 pandemic has had a global effect, causing psychological distress for many people. This research aims to determine the relationship between optimism and psychological distress among first-year students during the Covid-19 pandemic. This research performed using the quantitative method with non-probability sampling applied with a quota sampling technique and obtained a sample of 100 first-year students at Universitas Hang Tuah (UHT). Optimism was measured using Life Orientation Test-Revised (LOT-R) developed by Scheier, Carver, and Bridges. Psychological distress was measured by the Kessler Psychological Distress Scale (K10) developed by Kessler and Mroczek. The results of the data analysis using Spearman Rank-order showed a correlation coefficient $\left(r_{s}\right)$ of -.395 with a value of $p=.000(p<.01)$. This demonstrates that there is a negative relationship between optimism and psychological distress among first-year students during the Covid-19 pandemic. The results also reveal that the majority in the level of optimism and psychological distress among first-year students of UHT is in the high category.
\end{abstract}

Keywords: optimism; psychological distress; students; the Covid-19 pandemic

\section{INTRODUCTION}

The world is currently shocked by this outbreak of the Covid-19 virus. This epidemic has spread all over the world, including Indonesia. The WHO declared Covid-19 a global pandemic and to break the chain of the transmission of this virus, people are encouraged to practice physical distancing, activities involving large numbers of people are avoided, and this of course affects all aspects of life including education. According to UNESCO, due to the Covid-19 pandemic, school activities of nearly 300 million students worldwide have been disrupted and this threatens their educational rights in the future (Handoyo, 2020).

Based on The Circular Letter of The Minister of Education and Culture number 36962/MPK.A/HK/2020 'regarding online learning and working from home in order to prevent the spread of Covid-19', that to optimize government instructions related to physical distancing, learning is changed to online (Ministry of Education and Culture [Kemdikbud], 2020). The change in the learning system which was originally face-toface to online could have an impact on students, especially new or first-year students. In addition, students are often referred to as 'experiencing age of instability' due to various transitions, such as the transition from high school to university and the transition from adolescence to early adulthood (Arnett et al., 2014). Therefore, these changing conditions have caused more frequent emotional fluctuations among new students who are in the late adolescence stage. Emotional fluctuations or age of instability in adolescents is a consequence of their efforts to adjust to new behavior patterns and new social expectations.

The Covid-19 pandemic has had an impact on the psychological condition of students. A study conducted by Zulva (2020) showed that individuals respond to environmental conditions with excessive anxiety. Information about Covid-19 caused individuals to react in a psychosomatic way due to tension, anxiety, and panic (Zulva, 2020). This condition is in line with the results of a study by Afendi and Nurkholis (2020) 
that the psychological impact caused during the Covid-19 pandemic includes anxiety or excessive fear that results in panic buying as well as experiencing feelings of depression, stress, and anxiety. Based on the results of a survey conducted by the Association of Indonesian Psychiatric Specialists (PDSKJI) $64.3 \%$ of 1,522 respondents who joined the online self-examination regarding mental health impacts of the Covid-19 pandemic, were found to suffer from psychological problems of anxiety or depression. In addition, as many as $80 \%$ of the respondents experienced psychological trauma related to Covid-19 and endured symptoms of psychological post-traumatic stress due to witnessing unpleasant events related to Covid-19. Of the respondents who experienced psychological trauma $46 \%$ experienced severe symptoms, $33 \%$ moderate symptoms, $2 \%$ mild symptoms, and $19 \%$ no symptoms (Aziz, 2020).

Research conducted by Sari (2020) regarding the stress levels of students in dealing with the Covid-19 outbreak and online lectures showed that the largest number of students experienced moderate stress $38.57 \%$, some experienced severe stress $28.57 \%$, and mild stress at $32.86 \%$. Stressors that contributed a big influence on stress were difficulty understanding materials delivered and fear of contracting Covid-19 (Sari, 2020). This conclusion is in line with the results of a survey conducted on 1,200 lecturers and students at various campuses in Indonesia which found that more than $50 \%$ respondents, especially at state universities, confirmed that they had never done online learning before (Dzulfikar et al., 2020). Similar results were also published by Harahap et al. (2020) who conducted research on the analysis of academic stress levels in students during online learning during this period, the results obtained showed that on average students experienced stress in the moderate category $(75 \%)$.

In psychology, anxiety and depression are dimensions of psychological distress
(Mirowsky \& Ross, 2017). Psychological distress itself is a part of stress which is a psychological condition that arises when individuals feel they do not have the capacity to deal with environmental demands effectively (Biggs et al., 2017). Mirowsky and Ross (2002) define psychological distress as a state of emotional suffering characterized by symptoms of depression (such as loss of interest, sadness, hopelessness) and anxiety (such as restlessness, feeling tense). The concept of distress comes from $\mathrm{H}$. Selye who states that "distress is a stress response that can result in something negative or physiologically and psychologically threatening" (Matthews \& Gallo, 2011). The inability to deal with stressors and the emergence of emotional turmoil when exposed to emotional situations is one of the causes of psychological distress (Ridner, 2004).

According to Mirowsky and Ross (2017), psychological distress consists of two dimensions, depression and anxiety which are manifested in the form of mood (feelings) and malaise (physical state). The factors that can affect psychological distress include: (1) intrapersonal factors, namely the individual's traits and self-esteem; (2) situational factors, which consist of: (a) physiological, such as parts of the brain, age, or gender; (b) cognitive processes, individual's beliefs and expectations depending on the individual's evaluation of the external conditions; (c) social, such as grieving situations, marital status, socioeconomic status, and the presence of social support (Liu \& Chen, 2012; Matthews \& Gallo, 2011; Mirowsky \& Ross, 2017). When individuals experience instability and adjustment to changes that occur, those individuals can maintain or cope with stress especially distress within themselves. This can happen because of the protection factor, the protective factors of distress are forgiveness, self-esteem, resilience, and optimism (Rey et al., 2019). Optimism is one of the protective factors of psychological distress because of its role in overcoming the two syndromes of 
psychological distress, depression, and anxiety (Mirowsky \& Ross, 2017; Rey et al., 2019).

Chang et al. (2017) define optimism as an individual's expectation that good things will happen, in other words an optimistic individual is an individual who believes that something positive will occur in the future. Bastianello et al. (2014) state that optimism is a stable personality trait and is associated with positive expectations of future outcomes. Individuals who interpret life pessimistically have impacted growing feelings of hopelessness and depression (Goleman, 1997). Nes and Segerstorm (2006) say that optimism affects how a person sees the world (appraisal) and their behavior in it (effort). Optimistic individuals believe that they are capable of taking action to achieve positive results (Carver et al., 2010). In contrast to optimistic individuals, pessimistic individuals see a problem from the opposite perspective, they tend to be more indecisive and believe things will not go as desired (Carver et al., 2010).

Segerstrom et al. (1998) claim that optimism has a positive role on psychological and physical conditions. The positive role of optimism can also be seen from research conducted by Jahanara (2017) which examined the relationship between hope, optimism, and mental health (psychological well-being and psychological distress) among students at the University of Pune in India. The results of the research revealed that optimism has a significant relationship with psychological distress and psychological well-being among students in India. It is also reinforced by research conducted by Shaheen (2015) on the relationship between optimism and self-esteem with psychological distress among students in India, the results obtained from this research was that there is a significant negative relationship between optimism and psychological distress as well as a negative relationship between self-esteem and psychological distress among students. Similar results were also identified by
Hutapea and Sri (2019) who examined the relationship between optimism and psychological distress in poor emerging adults in DKI Jakarta, results obtained from this research was that optimism had a significant negative relationship with psychological distress.

Based on studies and previous research on optimism and psychological distress, we find out that optimism can affect the level of depression and anxiety in individuals who always think positively and are oriented towards the idea that good things will happen. However, in Indonesia, there are not many studies discussing psychological distress among first-year students during the Covid-19 pandemic, because it is a new situation, and it has caused many activities to be disrupted such as changes to the lectures system. This research has its own novelty and uniqueness, to reveal the relationship between optimism and psychological distress among first-year students during the Covid-19 pandemic. It was important to write this article to find out the level of psychological distress among students during the outbreak and its relationship to their levels of optimism. Is there a significant negative relationship between optimism and psychological distress among first-year students? This research aims to determine whether or not this is indeed the case.

\section{METHOD}

This research used data in the form of numbers and data analysis using statistical techniques. The type of research performed was associative research. The population of subjects in this research was 100 first-year students of Universitas Hang Tuah Surabaya. This was obtained based on the sampling technique used in this research, nonprobability sampling using quota sampling techniques. The subject characteristics in this research was the first-year students of Universitas Hang Tuah Surabaya. A survey was conducted for data collection method, because the research took samples from one 
population and questionnaires were presented as the main data collection tool, all questionnaires adopted in this research were administered to participants in Indonesian. All data analysis in this research applied with the help of IBM SPSS Statistics 25 software.

The measuring instrument for assessing psychological distress in this research was Kessler Psychological Distress Scale (K10) developed by Kessler and Mroczek in 1994 which was translated into Indonesian by researchers. K10 is a self-report measuring tool that contains 10 items or statements about symptoms of depression and anxiety experienced by individuals in the previous four weeks. The items applied for example "In the past 4 weeks, how often did you feel tired out, for no good reason?". Each item was answered using a Likert scale consisting of five points, ranging from SS (very often), S (often), N (neutral or normal), TS (not often), and STS (very rarely). The scoring system adopted was based on a method developed by the Clinical Research Unit for Anxiety and Depression at the University of New South Wales. The results of K10 scale score range from 10 to 50 (Winefield et al., 2012). The results of the reliability test obtained Cronbach's alpha value of .873 . The items validity test using item-total correlation showed that all items are concluded to be valid (i-r correlation > .3), therefore we can confirm that $\mathrm{K} 10$ has a high validity and is reliable or very strong (Sugiyono, 2013). This, according to Sugiyono (2013), indicates that K10 scale is able to provide near accurate results (slight error) and provide the same results even though the measurements are carried out many times.

The measuring instrument for assessing optimism was Life Orientation Test-Revised (LOT-R) developed by Scheier et al. (1994) and was translated into Indonesian by researchers. LOT-R consists of 10 items, and it is unidimensional with 3 items measuring optimism (positive), 3 items measuring pessimism (negative), and 4 filler items or distractors which served as a diversion only and were not used for assessment purposes.
The items applied, such as "In uncertain times, I usually expect the best", "If something can go wrong for me, it will", and "I don't get upset too easily". Each item is answered using a Likert scale consisting of five points, ranging from SS (very often), S (often), N (neutral or normal), TS (not often), and STS (very rarely). When calculating by statistical analysis, the scores of negative items or those measuring pessimism are reversed so that a score close to 5 always indicates a high level of individual optimism (Scheier et al., 1994). The higher the total scores obtained, the higher the level of optimism. The results of the reliability test obtained Cronbach's alpha value of .722 which can be interpreted as being in the strong category (Sugiyono, 2013). The items validity test using item-total correlation showed that all items are concluded to be valid (i-r correlation > .3). Therefore, we can conclude that LOT-R holds a high validity and is reliable (strong).

Descriptive statistics were adopted to analyze data in this research by examining the frequency and percentage of subjects based on gender and categories of psychological distress and optimism. For the purposes of data analysis, a prerequisite test was first conducted using normality and linearity tests, and the results showed that the distribution of the data was not normal and there was a significant linear relationship between optimism and psychological distress. Due to the data distribution that was not properly administered, hypothesis testing was performed using Spearman's Rank-order correlation test.

\section{RESULT AND DISCUSSION}

The subjects in this research were 100 firstyear students, a total of $57 \%$ subjects were female and $43 \%$ were male with an age range between 19 to 21 and were in the year of entry (class of) 2019.

The descriptive data of psychological distress was obtained from the results of the responses to the K10 scale given to the research subjects. 
The K10 scale consists of 10 items whose scores rank from 1 to 5 . The response categorization used on the psychological distress scale ranged from 1 to 5 . In table 1, we can see that the mean value is 32.76 and $S D$ is 8.170. Compared with the results of the research conducted by Shaheen (2015), this shows a relatively different and higher average even though it used similar sample characteristics, students.

The descriptive data of optimism was obtained from the results of the responses to the LOT-R scale given to the research subjects. The LOT-R scale consists of 6 items with a score range from 1 to 5 . The response categorization used on the optimistic scale ranges from 1 to 5 . In table 1 , we can see that the mean value is 20.62 and $S D$ is 2.477 . Compared with the results of the research conducted by Shaheen (2015), this shows a relatively different and higher average even though with similar sample characteristics, students. The reason for this could be that the challenges encountered are more complex due to the Covid-19 pandemic.

Table 1.

Description of Data for Each Variable

\begin{tabular}{cccccc}
\hline Variables & Min & Max & Mean & Median & SD \\
\hline $\begin{array}{c}\text { Psychological } \\
\text { Distress }\end{array}$ & 12 & 44 & 32.76 & 34 & 8.170 \\
\hline Optimism & 15 & 26 & 20.62 & 21 & 2.477 \\
\hline
\end{tabular}

Based on the description of the data, score categorization for psychological distress and optimism can be done using the median as the categorization limit because the data distribution is not normal. Table 2 shows that 53 subjects (53\%) had a high level of psychological distress, and 47 subjects (47\%) had a low level of psychological distress. From the results of the categorization, we find out that the number of subjects who had a high level of psychological distress was more than the number of the subjects who had a low level of psychological distress. Therefore, the conclusion is that most of the research subjects had a high level of psychological distress.

Data from Table 2 shows that 52 subjects $(52 \%)$ who had a high level of optimism and as many as 48 subjects ( $48 \%$ ) had a low level of optimism. From the results of the categorization, we find that 52 first-year students of Universitas Hang Tuah who engaged as research subjects had a high level of optimism. Therefore, the conclusion is that most of the research subjects had a high level of optimism.

\section{Table 2.}

Score Categorization

\begin{tabular}{cccc}
\hline Variables & $n$ & $\%$ & Category \\
\hline Psychological & 47 & $47 \%$ & Low \\
\cline { 2 - 4 } Distress & 53 & $53 \%$ & High \\
\hline \multirow{2}{*}{ Optimism } & 48 & $48 \%$ & Low \\
\cline { 2 - 4 } & 52 & $52 \%$ & High \\
\hline
\end{tabular}

Based on statistical analysis to assess the hypothesis using the Spearman's Rank-order correlation test, the results obtained are $r_{s}=$ $.395, p=.000$, where the chosen significance level is $\alpha=.05$. From these results, we can interpret that the correlation strength between optimism and psychological distress is low or weak (Sugiyono, 2013). However, the significance value indicates that the correlation coefficient obtained is statistically significant, so the research hypothesis which states that there is a negative relationship between optimism and psychological distress among first-year students during the Covid-19 pandemic is accepted. The relationship between optimism and psychological distress in this research shows a negative direction, meaning that the higher the level of optimism, the lower the level of psychological distress. 
Conversely, the lower the level of optimism, the higher the level of psychological distress.

These results are in line with previous research, such as those conducted by Taylor et al. (2012) and Kim et al. (2014) which state that optimism has a significant and negative relationship with the level of individual psychological distress. A research conducted by Jahanara (2017) found that optimism has a significant relationship with psychological distress and psychological well-being among students in India. This is also reinforced by research conducted by Shaheen (2015) which shows that there is a significant negative relationship between optimism and psychological distress among students. Similar results were also found by Hutapea and Sri (2019) who examined the relationship between optimism and psychological distress among poor emerging adults in DKI Jakarta, it was found that optimism has a significant negative relationship with psychological distress. The results of this research are also in accordance with Andersson's (1996) statement which specifies that optimism can be a protective factor from psychological distress.

Individuals with optimism believe that in the future they will achieve good results, whereas individuals with pessimism believe that in the future they will receive bad results. Differences in expectations or beliefs form perceptions and perspectives on different stressors. With the first-year students, those individuals experience the age of instability due to various transitions, such as the transition from high school to university and from adolescence to early adulthood. Therefore, these changing conditions cause emotional fluctuations that are more frequent than before. These emotional fluctuations or age of instability in adolescents is a consequence of their efforts to adapt to new behavior patterns and new social expectations. In addition, the Covid-19 pandemic has had an impact on the psychological condition of students. According to Zulva (2020), the pandemic causes individuals to respond to environmental conditions with excessive anxiety. The change in the learning system which was originally face-to-face to online has also had an impact on first-year students and can be a source of stressors for students.

Individuals who interpret life pessimistically, generate growing feelings of hopelessness and depression (Goleman, 1997). According to Nes and Segerstrom (2006) optimism affects how a person sees the world (appraisal) and their behavior in it (effort). Optimistic individuals believe that they are capable of taking action to achieve positive results. In contrast to optimistic individuals, pessimistic individuals see a problem from the opposite perspective. Pessimistic individuals tend to be more indecisive and believe that things will not go as desired (Carver et al., 2010). They have slow responses in solving problems, often surrender, can be overly passive and full of denial (Berkel, 2009). According to this research, most of the subjects who are the first-year students hold a high level of optimism. Despite the Covid-19 pandemic that they are currently experiencing, most of the first-year students expect good things to happen in their lives in the future.

On the other hand, individuals who experience psychological distress (depression and anxiety) tend to be less oriented towards the future. Psychological distress is characterized by depression (such as loss of interest, sadness, hopelessness) and anxiety (such as restlessness, feeling tense). The inability to deal with stressors and the emergence of emotional turmoil when exposed to stressful situation is one of the causes of psychological distress (Ridner, 2004). In this research, as many as $53 \%$ of the first-year students have experienced a high level of psychological distress during the Covid-19 pandemic. This indicated from their emotional levels of the previous four weeks, feeling exhausted for no apparent reason, feeling nervous or anxious, depressed, agitated or worried, feeling worthless, and finding very little peace and comfort. 
The results of this research indicate that there is a negative relationship between optimism and psychological distress among first-year students during the Covid-19 pandemic. Thus, we can conclude that optimism can minimize the possibility of first-year students experiencing psychological distress during the pandemic. On the other hand, lower levels of optimism can cause a higher level of psychological distress among first-year students during the pandemic.

\section{CONCLUSION}

Based on the results of research and data analysis, we can summarize that there is a relationship between optimism and psychological distress among first-year students during the Covid-19 pandemic, although the correlations strength between optimism and psychological distress is relatively weak. Optimism and psychological distress have a negative correlation, meaning that the higher the level of optimism, the lower the level of psychological distress. On the contrary, the lower the level of optimism, the higher the level of psychological distress. The limitation of this research is that the author does not use demographic data for further research, because this research focuses on the relationship between optimism and psychological distress. Further research should pay more attention to other factors that can also affect psychological distress and analyze this based on demographic data, so that new information can be added and provide a more specific picture of variables related to psychological distress. As for information on the description of the level of psychological distress, optimism, and relations between the two, this research can be used as a reference for creating intervention programs in the form of training to reduce psychological stress that can occur among students during the Covid-19 pandemic.

\section{REFERENCES}

Afendi, A. H., \& Nurkholis, N. (2020). Dampak pandemi Novel-Corona Virus
Disease (Covid-19) terhadap psikologi dan pendidikan serta kebijakan pemerintah. Jurnal PGSD, 6(1), 39-49. doi: 10.32534/jps.v6i1.1035

Andersson, G. (1996). The benefits of optimism: A meta-analytic review of the life orientation test. Personality and Individual Differences, 21(5), 719-725. doi: 10.1016/0191-8869(96)00118-3

Arnett, J. J., Rita, Z., \& Kazumi, S. (2014). The new life stage of emerging adulthood at ages 18-29 years: Implications for mental health. Lancet Psychiatry, 1(7), 569-576. doi: 10.1016/S22150366(14)00080-7

Aziz, A. (Ed.). (2020, May 1). Survei: 64,3\% dari 1.522 orang cemas \& depresi karena Covid-19. Retrieved June 1, 2020, from https://tirto.id/survei-643-dari-1522orang-cemas-depresi-karena-Covid-19fgPG.

Bastianello, M., Pacico, J., \& Hutz, C. (2014). Optimism, self-esteem, and personality: Adaptation and validation of the Brazilian Version of the Revised Life Orientation Test (LOT-R). Revista Psico-USF, 19(3), 523-531. doi: 10.1590/1413$\underline{827120140190030}$

Berkel, H. V. (2009). The relationship between personality, coping styles and stress, anxiety and depression [Unpublished master's thesis]. University of Canterbury.

Biggs, A., Brough, P., \& Drummond, S. (2017). Lazarus and Folkman's psychological stress and coping theory. In C. L. Cooper \& J. C. Quick (Eds.), The handbook of stress and health: A guide to research and practice (1st ed., pp. 349- 
364). John Wiley \& Sons Ltd. doi: 10.1002/9781118993811.ch21

Carver, C. S., Scheier, M. F., \& Segerstrom, S. C. (2010). Optimism. Clinical Psychology Review, 30(7), 879-889. doi: $\underline{10.1016 / j . c p r .2010 .01 .006}$

Chang, E. C., Chang, O. D., Martos, T., Sallay, V., Li, X., Lucas, A. G., ... Li, X. (2017). Does optimism weaken the negative effects of being lonely on suicide risk? Death Studies, 42(1), 63-68. doi: $\underline{10.1080 / 07481187.2017 .1332115}$

Dzulfikar, L. T., Daryono, \& Tian, B. (2020). Kuliah dari rumah akibat Covid-19 banyak kendala: Belajar dari keberhasilan Universitas Terbuka. Retrieved June 1, 2020, from https://theconversation.com/kuliah-darirumah-akibat-Covid-19-banyak-kendalabelajar-dari-keberhasilan-universitasterbuka-137230

Goleman, D. (2015). Emotional intelligence: Kecerdasan emosional mengapa EI lebih penting daripada IQ. PT Gramedia Pustaka Utama.

Handoyo. (2020, March 6). UNESCO: Wabah virus corona ancam pendidikan 300 juta siswa. Retrieved June 1, 2020, from https://amp.kontan.co.id/news/unescowabah-virus-corona-ancam-pendidikan300-juta-siswa.

Harahap, A. C. P., Dinda, P. H., \& Samsul, R. H. (2020). Analisis tingkat stres akademik pada mahasiswa selama pembelajaran jarak jauh dimasa Covid-19. Biblio Couns: Jurnal Konseling dan Pendidikan, 3(1), 10-14. doi: 10.30596/biblio couns.v3il.4804
Hutapea, C. D. A., \& Sri, F. M. (2019). Hubungan antara optimisme dan distres psikologis pada emerging adults miskin di DKI Jakarta. Mind Set, 10(2), 87-103. doi: $\underline{10.35814 / \mathrm{mindset} . v 10 \mathrm{i} 02.1129}$

Jahanara, M. (2017). Optimism, hope and mental health: Optimism, hope, psychological well-being and psychological distress among students, University of Pune, India. International Journal of Psychological and Behavioral Sciences, 11(8), 451-455. doi: $\underline{10.5281 / \text { zenodo. } 1131553}$

Kementerian Pendidikan dan Kebudayaan. (2020, March 17). SE Mendikbud: Pembelajaran secara daring dan bekerja dari rumah untuk mencegah penyebaran Covid-19. Retrieved June 1, 2020, from https://www.kemdikbud.go.id/main/blog/ 2020/03/se-mendikbud-pembelajaransecara-daring-dan-bekerja-dari-rumahuntuk-mencegah-penyebaran-covid19.

Kim, E. S., Smith, J., \& Kubzansky, L. D. (2014). Prospective study of the association between dispositional optimism and incident heart failure. Circulation: Heart Failure, 7(3), 394-400. doi:

10.1161/CIRCHEARTFAILURE. 113.00 $\underline{0644}$

Liu, R. X., \& Chen, Z. Y. (2012). Adverse school experiences and psychological distress: The moderating effects of gender and perceived parental support. In $\mathrm{H}$. Ohayashi and S. Yamada (Eds.). Psychological distress: Symoptoms, causes, and coping (pp. 1-26). Nova Science Publishers, Inc. From: https://www.researchgate.net/publication/ 287509850_Adverse_school_experiences and_psychological_distress_The_moder 
ating_effects_of_gender_and_perceived parental_support

Matthews, K. A., \& Gallo, L. C. (2011). Psychological perspectives on pathways liking socioeconomic status and physical health. Annual Review of Psychology, 62(1), 501-530. doi: 10.1146/annurev.psych.031809.130711

Mirowsky, J., \& Ross, C. E. (2002). Measurement for a human science. Journal of Health and Social Behavior, 43(2), 152-170. doi: 10.2307/3090194

Mirowsky, J., \& Ross, C. E. (2017). Social causes of psychological distress (2nd ed). Routledge. doi: 10.4324/9781315129464

Nes, L. S., \& Sugerstrom, S. C. (2006). Dispositional optimism and coping: A meta-analytic review. Personality and Social Psychology Review, 10(3), 235251. doi: $10.1207 / \mathrm{s} 15327957 \mathrm{pspr} 1003$ 3 3

Rey, L., Cirenia, Q., Sergio, M., \& Natalio, E. (2019). Being bullied at school: Gratitude as potential protective factor for suicide risk in adolescents. Frontiers in Psychology, 10(1), 662-671. doi: $\underline{10.3389 / f p s y g .2019 .00662}$

Ridner, S. H. (2004). Psychological distress: Concept analysis. Journal of Advanced Nursing, 45(5), 536-545. doi: 10.1046/j.1365-2648.2003.02938.x

Sari, M. K. (2020). Tingkat stres mahasiswa S1 keperawatan tingkat satu dalam menghadapi wabah Covid-19 dan perkuliahan daring di Stikes Karya Husada Kediri. Jurnal Ilmiah Pamenang, 2(1), 31-35. https://jurnal.stikespamenang.ac.id/index. php/jip/article/download/36/16
Scheier, M. F., Carver, C. S., \& Bridges, M. W. (1994). Distinguishing optimism from neuroticism (and trait anxiety, selfmastery, and self-esteem): A reevaluation of the Life Orientation Test. Journal of Personality and Social Psychology, 67(6), 1063-1078. doi: 10.1037/0022$\underline{3514.67 .6 .1063}$

Shaheen, F. (2015). A study of optimism and self esteem in relation to psychological distress among professional and non professional students. International Journal of Education and Psychological Research (IJEPR), 4(1), 65-68. http://ijepr.org/panels/admin/papers/162ij $\underline{15 . p d f}$

Sugiyono. (2013). Statistika untuk penelitian. Alfabeta.

Taylor, Z. E., Widaman, K.F., Robins, R.W., Jochem, R., Early, D.R., \& Conger, R.D. (2012). Dispositional optimism: A psychological resource for Mexicanorigin mothers experiencing economic stress. Journal of Family Psychology, 26(1), 133-139. doi: 10.1037/a0026755

Winefield, H. R., Gill, T. K., Taylor, A. W., \& Pilkington, A. R. (2012). Psychological well-being and psychological distress: Is it necessary to measure both? Psychology of Well-Being: Theory, Research and Practice, 2(3), 1-14. doi: 10.1186/22111522-2-3

Zulva, T. N. I. (2020). Covid-19 dan kecenderungan psikosomatis. Journal of Chemical Information and Modeling, 53(9), 1-4. doi: $\underline{10.1017 / \mathrm{CBO} 9781107415324.004}$ 